\title{
Motivation and Awareness of Institutional Repositories by Students of Yogyakarta Islamic University of Yogyakarta and Yogyakarta State University
}

\author{
Santana Sembiring \\ Universitas Gadjah Mada
}

Paper Type:

Research Paper

\section{Abstract}

Background of the study: Institutional repositories are considered as one of the appropriate tools used by universities to store, preserve, and disseminate the scientific work of students and lecturers. Open access to institutional repositories allows students to access scientific works openly and they can get more complete parts of the work. However, there is another side of the institutional repository that has not received much attention, namely motivation and awareness about institutional repositories. Supported by data on student access to very high institutional repositories, this research was conducted at two universities in Yogyakarta, UII, and UNY.

Purpose: This study aims to find out what motivations UII and UNY students to use institutional repositories and what is the awareness of UII and UNY students about institutional repositories.

Method: The method used is qualitative with data collection techniques in the form of interviews with six UII and UNY students obtained based on snowball sampling techniques.

Findings: The main motivation of UII students to use institutional repositories is to obtain references while the motivation of UNY students is because the institutional repositories are easy to use tools. In terms of awareness, UII and UNY students have a different awareness about institutional repositories which lie in knowledge, semester, understanding, medium, and willingness to store academic work in institutional repositories.

Conclusion: Motivation and awareness are the two main keys that students must possess to succeed in the sustainability of the institution's repository.

Keywords: Institutional repository, open access, motivation, awareness, UII repository, $U N Y$ repository.

To cite this document:

Sembiring, S. (2020). Motivation and Awareness of Institutional Repositories by Students of Yogyakarta Islamic University

of Yogyakarta and Yogyakarta State University. Record and Library Journal, 6(2), 146-154

Open access under Creative Commons Attribution-Non Commercial-Share A like 4.0 International Licence

(CC-BY-SA) 


\section{Introduction}

The presence of information and communication technology that is growing rapidly and is supported by the availability of easily accessible information makes scientific literature such as journals, theses, theses, dissertations and other gray literature that anyone can get quickly and for free. In the academic community itself, born movement that is considered important in the sphere of scientific communication, movement is called open access or open access movement. The purpose of this motion is to eliminate barriers to access to the results of the study so that the spread of its can most reach a wider public. De Silva and Vance (2017) say open access to the scientific contents can make communication, scientific become two directions, resulting in a collaboration of various disciplines are different, community expands and opens new approaches that had not been used.

The university also had a role in creating an open access to the database is online contains the content-scientific content (Cullen and Chawner, 2011; UNESCO, 2015). One of them is the institutional repository, Prabhakar and Rani (2018) said that institutional repositories are the right means to manage, preserve the knowledge base and intellectual assets of the institution. Campbell (2011) add the repository institutions taking part role to assist the process of scientific communication by making access are sustainable and can change the role of libraries that were previously passive to more activity. The open access model adopted by institutional repositories is Green Open Access. De Silva and Vance (2017) state that Green Open Access is a practice of writers who save their research results themselves and then publish them through personal websites or institutional repositories so that everyone can read and access them. A kses open on institutional repository aims to make students or the general public could be getting a chance and equal rights to acquire the scientific literature by students or faculty work. Availability and ease in accessing content, institutional repository also can give effect to the development of further research.

Based on previous studies, the growth of repositories institutions in Indonesia for the last 10 also increases. Research Abrizah et.al, in 2010 said repository institutions in Indonesia just touch the figure of $3 \%$ only. In 2015, Paul and Basu (2015) said repository institutions in Indonesia is quite a good number continues to grow reaching 38 repository institutions. In 2017, the number of institutional repositories, open access in Indonesia had reached number 55 repositories (Seo, 2017) and in the year 2019 open (July 18 2019) said that Indonesia now has 104 repository of institutional open access. Based on the data and manual observations by the author, it is known that there are 15 provinces in Indonesia that already have open access repositories. The provinces are North Sumatra, West Sumatra, Riau, DKI Jakarta, North Kalimantan, Yogyakarta Special Region (DIY), East Java, Aceh, South Sumatra, South Sulawesi, South Kalimantan, West Java, Bali, Central Java, and West Kalimantan. If the territorial scope is narrowed, DIY Province it already has 23 institutional repositories from both state and private universities. The number 23 the author obtained from the results of manual observations of 112 tertiary institutions in Yogyakarta. However, after thorough observation, the authors found only 3 universities that have adopted open access to their institutional repositories, Yogyakarta Muhammadiyah University (UMY), Indonesian Islamic University (UII), Yogyakarta State University (UNY).

The presence of institutional repositories provides equal rights and opportunities for students as a whole to access and use content in the institutional repositories. The existence of an open access policy on institutional repositories makes it easier for students to obtain and fully understand the contents of scientific works written by students or lecturers without having to be burdened with copyright issues and acts of plagiarism. Apart from the simplicity side, there is another side of institutional repositories that have not received sufficient attention, motivation and awareness about institutional repositories (Bamingbola, 2014; Manchu and Vasudevan, 2018; Yang and Li, 2015). Yang and Li (2015) state that so that the maximum benefits of institutional repositories can be obtained, it is important to be aware of their existence, understand their value and the desire to use them. Meanwhile, Bamigbola (2014) and Dolan (2011) state that institutional repositories are built on the basis of disseminating scientific papers with open access so that it is interesting to examine the contents of their use because it is useless if institutional repositories are made with large funds but few use them.

Research on student awareness about institutional repositories has actually been carried out by

To cite this document:

Sembiring, S. (2020). Motivation and Awareness of Institutional Repositories by Students of Yogyakarta Islamic University

of Yogyakarta and Yogyakarta State University. Record and Library Journal, 6(2), 146-154

Open access under Creative Commons Attribution-Non Commercial-Share A like 4.0 International Licence

(CC-BY-SA) (c) (1) (2) 
previous authors, although they show different results. Bamigbola research (2014), from the Department of Libraries, Archives and Information, University of Ibadan Nigeria. The method used was a survey with descriptive statistical analysis. The results of the survey showed that students' awareness of institutional repositories increased by about $60 \%$. Respondents admit having sufficient awareness of the institutional repository. Alemayehu (2010) conducted a case study research on how awareness and attitudes of 43 science writers at the University of Oslo in using institutional repositories, the findings show that the authors have low awareness of institutional repositories but are interested in saving and contributing so that their scientific work can be distributed through institutional repository and the writers also had a positive response to put their papers in order to be accessible in an open and through the institutional repository.

The conclusions of the above statements and studies indicate that institutional repositories have an important role in the dissemination of knowledge so it is important for students to have motivation and awareness about institutional repositories. In addition, research on motivation and awareness about institutional repositories of students in tertiary institutions in Indonesia has not received adequate attention.

In accordance with the problems and objectives, this research was carried out in 2 universities in Yogyakarta that have adopted open access institutional repositories, namely the Indonesian Islamic University Yogyakarta (UII) and Yogyakarta State University (UNY). The reason the authors chose the two universities was because of two things. First, only two colleges are already fully adopted the open access the institutional repository. Second, in this study, the authors need data related to student access to institutional repositories, and only these two universities can provide it.

UII and UNY institutional repositories are built on the basis that all student scientific research works can be accessed openly, fully and free of charge. The UII repository was created in 2008 which initially still used the INHERET system and then in 2013 until now UII manages its repositories using DSpace. The policy to implement open access to the UII repository began in 2008 with the aim of making UII research accessible to UII students and the general public. In the case of the use of the repository, access data of students to the institutional repository UII in the last three years ranging from 2016 to 2018 menunjukkan access high enough ie 398,609 with the number of students in the same three years as many as 25,959 .

The UNY's repository was built in 2010 but started operating in 2012 due to system changes. Starting from 2012 until now, the UNY repository is managed using e-prints. The open access policy to the repository began to be implemented in 2015 with the aim that the YSU repository could become a place for publications and the content contained therein could provide new insights into the academic world. UNY access the data repository within the last three years ranging from 2016 to 2018 also shows significant access, reaching 683,484 in comparison with the number of UNY students at three of the same year amounted to 20,414 .

Based on the data on the number of student accesses to the UII and UNY institutional repositories, it shows that students' attention to institutional repositories is very high. This can be seen from the vast difference in numbers between the number of accesses and the total number of students. The phenomenon of data access and student attention to institutional repositories is very high, making the authors interested in conducting more in-depth research on student motivation and awareness about institutional repositories. In accordance with the above problems, the questions in this study are: 1). What are the motivations for UII and UNY students to use institutional repositories? 2) What is the awareness of UII and UNY students about institutional repositories?

Regardless of the little or many research on institutional repositories in Indonesian universities, research on institutional repositories, especially motivation and awareness about institutional repositories for students, is still very little done in Indonesia and has not received adequate attention, so this is both interesting and at the same time. Important to be investigated more deeply.

To cite this document:

Sembiring, S. (2020). Motivation and Awareness of Institutional Repositories by Students of Yogyakarta Islamic University

of Yogyakarta and Yogyakarta State University. Record and Library Journal, 6(2), 146-154

Open access under Creative Commons Attribution-Non Commercial-Share A like 4.0 International Licence

(CC-BY-SA) (c) (1) (2) 


\section{Research Method}

The method used in this research is qualitative by conducting studies on student motivation and awareness about institutional repositories in 2 universities in Yogyakarta, the Islamic University of Indonesia (UII) and Yogyakarta State University (UNY). The reason the writer chose a qualitative approach was first, the writer wanted to know more in-depth information related to the motivation and awareness of UII and UNY students about institutional repositories. Second, with a qualitative approach the writer can get new facts or findings about the motivation and awareness of UII and UNY students about institutional repositories. Third, the authors want to get the original data from informants by meeting and having direct dialogue with informants from UII and UNY. Because the author needs original and actual data to answer research questions and research objectives with interview techniques, the authors choose a qualitative approach.

In accordance with the purpose of this study to determine student motivation and awareness about institutional repositories, the location of this research was conducted in 2 universities in Yogyakarta which have open access institutional repositories, the Islamic University of Indonesia (UII) and Yogyakarta State University (UNY).

The technique of determining the informants in this study used the snowball sampling technique. The sampling technique using snowball sampling is taking the number of samples that are getting bigger and bigger as the research progresses (Pawito, 2007). Usually the authors ask the informants to recommend other informants who can provide answers to interview questions and so on so that the data obtained gets bigger and bigger like snowballs gathered together. The number of UII informants that the author obtained was six informants. The writer also did the same way with UNY informants. So that the total samples obtained by the author based on the snowball technique amounted to 12 samples, six at UII and six at UNY.

The data collection techniques used in this study were in-depth interviews, observation and literature study. The interview process conducted by the author lasts a month. Precisely starting from the beginning to the end of May 2019. In conducting interviews, the author is assisted by a list or guidelines for interview questions and electronic devices such as smartphones with the aim of recording any information presented by the informant to the author. The observations made were observing the institutional repositories in each university that the author accessed from each repository page, where the information on that page could be interpreted into data and could provide information or descriptions of the complete results. For the literature study, the authors collect secondary data from various sources such as books, journals, and other research results both from within the country and abroad. For secondary data, the authors mostly use journal articles and books in electronic format. The journals and books used by the author are of course related to open access, institutional repositories, motivation and awareness.

The data analysis technique in this study used a model from Miles and Hubberman. The data analysis techniques of Miles and Hubberman are divided into three stages, starting from data reduction, data presentation and drawing conclusions. In this study, the author conducted data reduction after completing interviews with informants from UII and UNY. Furthermore, the authors conducted transcripts of all the results of the informant interviews both at UII and UNY in complete and detailed. After that, the authors filter the important data and if it needs to be asked back to the informant further. After conducting transcripts, the authors group the findings, according to their respective parts, namely, motivation to use institutional repositories and awareness of institutional repositories.

To make it easier for the writer to understand the situation that occurred, the writer made themes to be analyzed. Based on the results of the interview, the authors obtained three themes that are used to analyze student motivation (1) student motivation using institutional repositories, (2) student motivation using institutional repositories from different universities, and (3) the benefits of using institutional repositories. As for awareness, the authors obtained four themes, namely (1) knowledge of institutional repositories, (2) understanding institutional repositories, (3) medium knowing institutional repositories, (4) willingness to save academic works in institutional repositories. The existing themes, then the writer

To cite this document:

Sembiring, S. (2020). Motivation and Awareness of Institutional Repositories by Students of Yogyakarta Islamic University

of Yogyakarta and Yogyakarta State University. Record and Library Journal, 6(2), 146-154

Open access under Creative Commons Attribution-Non Commercial-Share A like 4.0 International Licence

(CC-BY-SA) (c) (1) (2) 
constructs into a discussion by adding statements from the informants so that it can make it easier to understand the data presented and described by the author in chapter IV.

\section{Results and Discussion}

\section{Motivation of UII and UNY Students to Use Institutional Repositories}

Universities such as UII and UNY have implemented an open access policy on institutional repositories. The essence of this policy is to increase and maximize repository utilization activities and the existence of institutional repositories is expected to contribute in the form of webometric ranking and google scholar. The activity of using institutional repositories as a source of knowledge renewal cannot be separated from motivation. In this section the writer wants to know what the motivation of UII and YSU students to use institutional repositories.

Based on the results of interviews with UII informants, most of their motivation to use the repository was due to academic needs. There are two types of specific academic needs. First, to get references and new ideas related to the final project and second to find out the guidelines for writing and preparing the final project. Another motivation is because he really wants to promote his research work to others through the UII repository. The authors found different findings on the informants of YSU regarding the motivation to use institutional repositories. The author found their main motivation to use the YSU repository because the repository is an easy-to-use tool in obtaining research information. In addition to the institutional repository, tools that are easy to use and obtain research references, the motivation for other UNY informants to use the repository is due to academic needs. This academic need requires a reference as a guide for writing and compiling a final project. YSU informants admit that since the first semester the Head of the Study Program has asked for research titles.

Overall, the motivation of informants, both UII and UNY, uses the institutional repository because it is based on academic needs. Specifically, the motivation of UII students to use institutional repositories because of their academic need is to obtain research references that can help them to develop and improve the quality of their research and final project. Reference from previous studies can be the basis for them to improve the quality of their research, because from this research they can develop theories, find gaps in cases and continue their research. These findings are in accordance with research conducted by the Manchu and Vasudevan (2018) who conducted research on the motivation and awareness of institutional repositories for Calicut University students in India. The results of his research indicate that the main motivation of students using institutional repositories is to develop and improve the quality of their research.

The authors found different motivations for informants at YSU, based on the results of the interviews, it was found that the main motivation for YSU informants was using institutional repositories because institutional repositories are easy to use tools. They don't need to register first to access and download the content in the repository, they just need to type a keyword and it doesn't take long for the repository to provide the references they need. Through institutional repositories they can access from anywhere without being bound by time and space. The main motivation of YSU students using the repository is because it is not in accordance with the research conducted by Dutta and Paul (2014). Their research results show that there is no motivation for students to use institutional repositories because of its convenience, the main motivation for students to use institutional repositories at Calcutta University in India is to expand the distribution of student papers through institutional repositories and there are regulations from the university so that every student work is deposited into the institutional repository. Likewise, research conducted by the Manchu and Vasudevan (2018) states that students' motivation to use institutional repositories because of its convenience is in third place while in the first place is to improve and improve the quality of student research.

The emergence of motivation comes from two sources, intrinsic motivation (inside), where someone does something because he really likes to do it and extrinsic motivation (outside himself), where someone is motivated to do an activity because there are external drivers such as rewards, rewards, punishment, and sanctions. Based on the results, UII students are more concerned with extrinsic

To cite this document:

Sembiring, S. (2020). Motivation and Awareness of Institutional Repositories by Students of Yogyakarta Islamic University

of Yogyakarta and Yogyakarta State University. Record and Library Journal, 6(2), 146-154

Open access under Creative Commons Attribution-Non Commercial-Share A like 4.0 International Licence

(CC-BY-SA) (c) (1) (2) 
motivation while YSU student motivation has intrinsic motivation and extrinsic motivation.

Their motivation is driven by demands and rules of the university which require that in writing a study or a final project must use a certain number of references, if this rule is not implemented then their research can be considered not in accordance with scientific research standards. UII students must also follow and refer to the guidelines for writing and drafting a final project in accordance with UII standards because the guidelines and writing arrangements for each faculty are different, if they do not follow the existing guidelines and arrangements then they may be reprimanded by the faculty and supervisors. Meanwhile, YSU students are motivated intrinsically and extrinsically. YSU students are happy when using institutional repositories, the reason is because the institutional repositories offer convenience in terms of obtaining content and for extrinsic motivation, YSU students must refer to the writing guidelines and their preparation is in accordance with the standards imposed by YSU, otherwise they will receive a warning from the lecturer supervisor.

\section{Motivation of UII and UNY Students to Use Institutional Repositories from Different Universities}

Institutional repositories are built by related universities to make it easier for students to obtain scientific literature by students and lecturers. However, sometimes the references that students are looking for do not find and do not fit in their own institutional repositories so they take the stance to use institutional repositories from different universities, with the hope that the scientific content contained therein can be used as a reference for their research or final project.

Based on the results of the interview, it is known that UII and UNY students even frequently used institutional repositories from various universities. They found the repository by accident because they previously did a keyword search through google and google scholar. In the practice of accessing repositories from other universities, UII and UNY students experience problems because most of the institutional repositories they find restrict access to certain parts.

On the motivational side, UII and UNY students use institutional repositories from different universities to improve and enhance their scientific communication, the way they do is (1) by adding references, (2) making comparisons of research they have done with other university students and (3) looking at the research developments that have been carried out by students from various universities. From the above findings, confirm the statement from Richardson and Wolksi (2012) which states that there are two important roles of institutional repositories in terms of the success of scientific communication. First, storing and maintaining the research results of an institution so that they can be used in the future and second, it can improve the quality of scientific communication by providing greater access to the research results of the institution.

\section{Benefits of Institutional Repositories for UII and YSU Students}

RATA (2017) said that with the existence of an institutional repository, the benefits that can be obtained are that student scientific works can be disseminated to the wider community quickly and easily and the institutional repository can also be a forum for students to publish their scientific works. UII and UNY students also benefit from the institutional repository.

Based on the data from the interview, the writer found that there were differences in the benefits of institutional repositories obtained by UII and UNY informants. The difference lies in the orientation and number. For UII informants, the main benefit they get is to assist in writing and drafting the final project, then another benefit is that it makes it easier for them to get references. Meanwhile, for YSU informants, the main benefit was that it made it easier for them to get references. Two other YSU informants did not get significant benefits due to differences in the standard guidelines for writing and drafting the final project with the supervisor, so that the two informants at YSU had to follow the guidelines suggested by the supervisor. If ordered according to the overall data from the interview results, the top two benefits are obtained. First, it makes it easier to get references and the second is to help with writing and preparing the final project. This is consistent with the statement of Barwick and Pickton (2006) especially with the first benefit, they say that one of the benefits of institutional repositories for scientific

To cite this document:

Sembiring, S. (2020). Motivation and Awareness of Institutional Repositories by Students of Yogyakarta Islamic University

of Yogyakarta and Yogyakarta State University. Record and Library Journal, 6(2), 146-154

Open access under Creative Commons Attribution-Non Commercial-Share A like 4.0 International Licence

(CC-BY-SA) (c) (1) (2) 
writers is to provide and offer easier and more flexible access to scientific content stored in institutional repositories. This makes it easier for writers to access and get the content they need.

\section{UII and UNY Student Awareness about Institutional Repositories}

Based on the results of interviews and referring to awareness themes that have been determined and analyzed, the authors found differences in the awareness of UII and UNY students about institutional repositories. The difference lies in knowledge, semester, understanding, medium and willingness to save academic work in the institutional repository. In terms of knowledge, UII students know more about UII Dspace than institutional repositories, while UNY students know the two terms, UNY e-prints and institutional repositories. From the semester side, YSU students know the institutional repositories faster than UII students. UII students begin to know the institutional repository in semesters 5 to 7 . Meanwhile, YSU students are the opposite, they know the institutional repository in the first semester. In terms of understanding, according to the authors, UNY students' understanding of institutional repositories is wider than UII students. YSU students understand that the institutional repository is not only a forum for student and lecturer, research collections, but the institutional repository is also understood as a place for publication and dissemination of research work. Meanwhile, UII students understand that the institutional repository is only limited to a container containing a collection of research produced by students and lecturers. From the medium side, UII students know that the institutional repository comes from two mediums, friends and the internet. Meanwhile, YSU students know that the institutional repositories come from three mediums, library staff, friends and the internet. In terms of willingness to save academic work in the institutional repository, only one UII student was unwilling to save his academic work in the institutional repository for fear of plagiarism. Meanwhile, UNY students as a whole are willing to save their academic work in the repository of the institution.

Based on the overall data from the results of interviews with UII students and YSU students in general, they already know and understand the concept of the institutional repository. This knowledge and understanding are obtained based on their experience when using institution repositories. In the previous discussion on the motivation section, UII students and YSU students found it very easy and helped by the existence of an institutional repository. If it is related to the theory of consciousness according to Zaiman (2001), then two main points of consciousness are fulfilled by UII and UNY students, namely awareness as experience and awareness as thought. Awareness as an experience, where UII and UNY students have their own experiences when using institutional repositories. Awareness as a thought, where UII and UNY students no longer feel worried and afraid of plagiarism if their academic work is stored and disseminated through the institutional repository. They feel that their research will be useless if it is kept only for themselves, on the contrary, they feel better if their research is stored and disseminated through the repository of the institution because it can provide more benefits for other students and society at large.

If it is related to the theory of the form of consciousness from Reinhardt et.al (2012) which states there are six forms of consciousness, then based on the findings of consciousness in UII and UNY students, their form of awareness is knowledge awareness (knowledge awareness). Knowledge, awareness is awareness related to one's ability to know and understand an object given by others. In terms of awareness of knowledge, although each informant at UII and UNY came from different faculties and semesters even though some were the same, they could each provide their knowledge and understanding of institutional repositories. They can tell well the definition and purpose of the institutional repository. This means that UII students and UNY students have awareness of knowledge about objects such as institutional repositories.

\section{Conclusion}

The presence of institutional repositories provides special experiences for UII and UNY students in terms of accessing and obtaining the scientific work they need. From the research results it is known that they use institutional repositories because they are based on academic needs, even though the academic needs of the two universities have different specifications. This means that students have an

To cite this document:

Sembiring, S. (2020). Motivation and Awareness of Institutional Repositories by Students of Yogyakarta Islamic University

of Yogyakarta and Yogyakarta State University. Record and Library Journal, 6(2), 146-154

Open access under Creative Commons Attribution-Non Commercial-Share A like 4.0 International Licence

(CC-BY-SA) (c) (1) (2) 
important role in the success of the sustainability of institutional repositories in terms of dissemination and renewal of knowledge through research. There are two things that can make the repository of an institution successfully even though universities and libraries must play a role in it, motivation and awareness. Two things are important to be owned by the students because it will be in vain if there are tools such as institutional repository which aims to facilitate students, but students do not have the desire to use it and do not know exists. For libraries, it is supposed to make regular socialization activities such as seminars or trainings that aim to make students aware of the importance of institutional repositories. Not only focusing on activities, information sources relating to institutional repositories also need to be made available to students, either through library sites, newsletters subscribed to by the library or through social media such as Facebook, Instagram, and Twitter.

This research was conducted because it was based on the lack of attention from Indonesian scientific writers regarding motivation and awareness about institutional repositories, especially in universities in Indonesia. So expect this research could fill a void and can be a trigger for students and universities in Indonesia to always succeed sustainability of institutional repository.

\section{References}

Abrizah, A., Noorhidawati, A., \& Kiran, K. (2010). Global visibility of Asian universities open access institutional repositories. Malaysian Journal of Library \& Information Science, 15(3), 53-73. Diakses dari https://jice.um.edu.my/index.php/MJLIS/article/view/6942

Alemayehu, M.W. (2010). Researchers attitude to using institutional repositories: A case study of the Oslo University Institutional Repository (DUO). (Master Thesis, Oslo University College, Oslo). Diakses dari https://oda.hioa.no/en/researchers-attitude-to-using-institutional-repositories-a-casestudy-of-the-oslo-university-institutional-repositoryduo/asset/dspace:1228/Alemayehu_MulukenWubayehu.pdf

Bamigbola, A.A. (2014). Surveying attitude and use of institutional repositories (IRs) by faculty in agriculture disciplines: A case study. Procedia Social and Behavioural Sciences, 147, 505-509. doi: 10.1016/j.sbspro.2014.07.145

Barwick, J., \& Pickton, M. (2006). A librarian's guide to institutional repositories. Elucidate, 3(2), 3-9. Diakses dari https://dspace.lboro.ac.uk/dspace-jspui/handle/2134/1122

Campbell, J. M. (2011). A framework for institutional repository development. Library Administration and Organizations, 30, 151-185. doi:10.1108/S0732-0671(2011)0000030006

Cullen, R., \& Chawner, B. (2010). Institutional repositories: Assessing their value to the academic community. Performance Measurement and Metrics, 11(2), 131-147. doi: $10.1108 / 14678041011064052$

Cullen, R., \& Chawner, B. (2011). Institutional repositories, open access, and scholarly communication: A study of conflicting paradigms. Journal of Academic Librarianship, 37(6), 460-470. doi: 10.1016/j.acalib.2011.07.002

De Silva, P.U.K., \& Vance, C.K. (2017). Scientific scholarly communication: The changing Landscape. doi: 10.1007/978-3-319-50627-2

Dolan, M. (2011). Assessing awareness of repositories and the open access movement among ETD faculty advisors. Proceedings of the $14^{\text {th }}$ International Symposium on Electronic Theses Dissertations (pp 13-17). Cape Town, South Africa. Diakses dari http://dl.cs.uct.ac.za/conferences/etd2011/papers/etd2011_dolan.pdf

Dutta, G., \& Paul, D. (2014). Awareness on institutional repositories related issues by faculty of University of Calcutta. Journal of Library \& Information Technology, 34(4), 293-297. doi: 10.14429/djlit.34.5138

Manchu O., \& Vasudevan T M. (2018). Awareness of institutional repositories and open access publishing among researchers in University of Calicut. International Research Journal of Library \& Information Science, 8(1), 43-51. Diakses dari http://irjlis.com/awareness-of-institutionalrepositories-and-open-access-publishing-among-researchers-in-university-of-calicut/

To cite this document:

Sembiring, S. (2020). Motivation and Awareness of Institutional Repositories by Students of Yogyakarta Islamic University

of Yogyakarta and Yogyakarta State University. Record and Library Journal, 6(2), 146-154

Open access under Creative Commons Attribution-Non Commercial-Share A like 4.0 International Licence

(CC-BY-SA) 
Opendoar. (2019). Browse by Country and Region. Diakses dari http://v2.sherpa.ac.uk/view/repository_by_country/id.html

Paul, M., \& Basu, A. (2015). A study on open access in Indonesia. International Journal of Library Science and Research, 5(4), 11-20. Diakses dari https://www.researchgate.net/profile/Anindya_Basu2/publication/281113258_A_Study_on_Ope n_Access_In_Indonesia/links/55d68d8408aec156b9a8655a/A-Study-on-Open-Access-InIndonesia.pdf?origin=publication_detail

Pawito. (2007). Penelitian komunikasi kualitatif. Diakses dari https://books.google.co.id/books?id=zN5iDwAAQBAJ\&printsec=frontcover\&dq=Penelitian+ko munikasi+kualitatif+Pawito\&hl=id\&sa=X\&ved=0ahUKEwjw8qrm1-

fhAhUJdCsKHUsxBeAQ6AEIKDAA\#v=onepage \&q=Penelitian\%20komunikasi\%20kualitatif\% 20Pawito\& $\mathrm{f}=$ false

Pinfield, S. (2009). Journals and repositories: An evolving relationship. Learned Publishing, 22(3), 165175. doi:10.1087/2009302

Prabhakar, S. V. R., \& Rani, S. V. M. (2018). Benefits and perspectives of institutional repositories in academic libraries. Scholarly Research Journal for Humanity science \& English Language, 5(25), 6904-6909. Diakses dari http://oaji.net/articles/2017/1201-1529139900.pdf

Richardson, J., \& Wolski, M. (2012). The importance of repositories in supporting the learning lifecycle. ICERI Conference Madrid, Spanyol, 2602-2608. Diakses dari https://core.ac.uk/download/pdf/143879521.pdf

Seo, Jeong-wook et al. (2017, Juni). Equality, equity, and reality of open access on scholarly information. Paper dipresentasikan di Korea OECD Workshop on Open Science \& Asian Science Editors Conference and Workshop, Vietnam. Diakses dari https://www.escienceediting.org/journal/view.php?number $=102$

UNESCO. (2015). Introduction to open access. Diakses dari https://unesdoc.unesco.org/in/rest/annotationSVC/DownloadWatermarkedAttachment/attach_im port_e21acac8-1e56-4950-ad9b-797305879377?_=231920eng.pdf

Usher, E. L., \& Morris, D.B (2012). Academic motivation. Encyclopedia of the Science of Learning (pp. 36-39). doi:10.1007/978-1-4419-1428-6_834

Yang, Z. Y., \& Li, Y. (2015). University faculty awareness and attitude towards open access publishing and the institutional repository: A case study. Journal of Librianship and Scholarly Communication, 3(1), 1-29. doi: 10.7710/2162-3309.1210

To cite this document:

Sembiring, S. (2020). Motivation and Awareness of Institutional Repositories by Students of Yogyakarta Islamic University

of Yogyakarta and Yogyakarta State University. Record and Library Journal, 6(2), 146-154

Open access under Creative Commons Attribution-Non Commercial-Share A like 4.0 International Licence

(CC-BY-SA)

(c) (1) (2) 